\title{
Economic Evaluation of the Resource-Saving Technologies in Non-irrigated Lands
}

\author{
Iroda Rustamova \\ Department of Agricultural Economics and Marketing, Tashkent State Agrarian University, Tashkent 100140, Uzbekistan
}

\begin{abstract}
Conservation agriculture (CA) is especially relevant for Uzbekistan's agriculture, particularly in non-irrigated lands where soil fertility has been steadily declining and the risk of crop failure has been growing. CA has three main characterizations given in scientific literature, which are the minimal soil disturbance, crop rotation and surface crop residue retention. Nowadays, the majority of farmers are not widely using CA in their agricultural practices in Uzbekistan. Maybe, this is due to different perception of the economic efficiency of CA. The objective of the research was to calculate economic efficiency of CA in non-irrigated lands and to show whether it is effective or not in agricultural production. To achieve this objective, literature review including a variety of secondary data is employed. Overall, the costs of labor and fuel consumption per ha at CA technology are less in comparison with conventional technology. Using CA practices gives a chance to increase labour productivity, to use resource effectively and to improve soil quality and crop diversification.
\end{abstract}

Key words: Conservation agriculture, productivity, economic efficiency, costs, profit, Uzbekistan.

\section{Introduction}

Nowadays in Uzbekistan, spiked cereals are sown over an area of more than 300 thousand ha in non-irrigated land mainly in fall period, of which approximately 180-200 thousand ha are sown and the rest part is fallow [1]. One of the most advanced soil-protecting and moisture-saving technologies that improve soil fertility is conservation agriculture (CA) - an innovative and distinguished technology for Uzbekistan's farmers, which is increasingly being used all over the world. The technology is particularly relevant to arid zones, where there is small quantity of rainfall and the risk of crop failure is very high in dry years. Therefore, the implementation of $\mathrm{CA}$ is especially relevant for Uzbekistan's agriculture, particularly in dry lands where soil fertility has been steadily declining and the risk of crop failure has been growing [1]. The studies show that crops, such as fodder beet and some other green crops and gourds, can not be sown using CA technology. Particularly,

Corresponding author: Iroda Rustamova, Ph.D., research field: agricultural economics. crops, such as wheat, triticale, corn, sorghum, sunflower, soybean, mung bean, sesame and others, are well suited for CA. They grow and develop well with the zero tillage even in the first years of its application.

CA has three main characterizations given in scientific literature, which are the minimal soil disturbance, crop rotation and surface crop residue retention [2]. Compared to conventional agriculture, CA practices differ in land and water management. Also, attitude of farmers (users) to CA is important factor, because farmers' perception of CA influences its implementation and development in agriculture. In Central Asia, CA may prevent salinity and degradation by water conservation [3]. CA is one of the options to combat environmental issues, such as land degradations and water scarcity [4]. Nowadays, the majority of farmers are not widely using CA in their agricultural practices in Uzbekistan. Maybe, this is due to different perception of CA. There are some factors that influence the implementations of CA, but one of the main reasons is considered as a lack of jointly collaborative work between actors [4]. 
Production level of cereals, vegetables, potatoes and fruits is increasing, and the amount of cotton production in the areas is decreasing simultaneously in Uzbekistan. This ensures food security by avoiding the lack of food and high prices for them. As a result of increase in harvesting of agriculture production and a decrease in the amount of cotton area, in 1991 cotton production was 4,646 thousand tons and in 2015 it was 3,497.2 thousand tons (decrease $24.8 \%$ relative to 1991). Also, cereal production increased from $1,908.2$ thousand to 7,500 thousand tons in 1991 and 2015 (about four times in 2015 relative to 1991). These indicators of agricultural products provide to cover all demand of Uzbekistan and give an opportunity to export these products sustainably $[5,6]$. Because of implementation of $\mathrm{CA}$ and other agro-innovation measures, the harvesting of agricultural products goes up and this indicator (one of the others) presents economic efficiency in agricultural production $[5,6]$. The objective of the research was to calculate economic efficiency of CA in non-irrigated lands and to show whether it is effective or not in agricultural production. This research may lead to development of implementation of CA in wider extent in Uzbekistan.

\section{Materials and Methods}

\subsection{Study Area}

Kashkadarya province is located in the South of Uzbekistan (Fig. 1). Kashkadarya province is a kind of "leader" in the regional economy of the country. It takes $6.4 \%$ of the territory, where $9.5 \%$ of the population of Uzbekistan live. The total land area of Kashkadarya province is $2,404.8$ thousand ha or $11.7 \%$ of the territory of Uzbekistan [7]. Main industries are energy, materials, light, food, flour and cereal products. The main branch of agriculture is cotton, farming, horticulture and viticulture, dairy cattle breeding, sheep breeding and sericulture. In 2013, the sown area is about 680.0 thousand ha, of which about half comes from pastures. The leading culture of the region (2013) was the wheat acreage, which amounted to 235.7 thousand ha, while the average

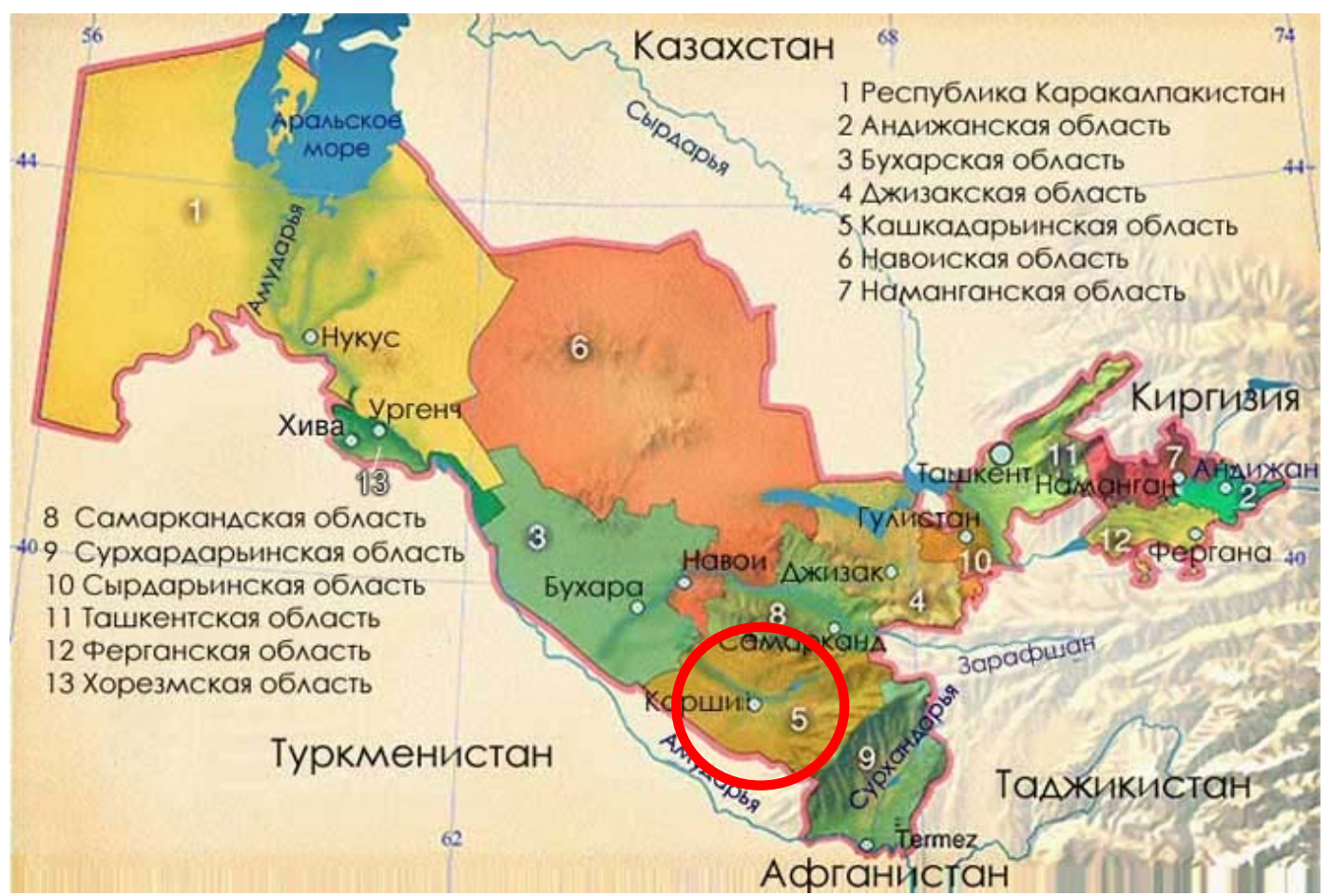

Fig. 1 Kashkadaya province (circled with red color) in the map of Uzbekistan. 
yield of $38.7 \mathrm{cwt}^{1} / \mathrm{ha}$. And $85.0 \%$ of wheat volume in 2013 was produced on farms [7].

The activities on implementing the resource-saving technologies (CA) in the non-irrigated lands were held in Kashkadarya (Uzbekistan) by agricultural scientist Aziz Nurbekov on the International Center for Agricultural Research in the Dry Areas (ICARDA) Project "knowledge management in the frame of phase II of the initiative of Central Asian countries on land resources management". Based on the research findings, the economic evaluation of $\mathrm{CA}$ for non-irrigated lands was carried out in the example of winter wheat cultivation [1].

The analysis of the introduction and implementation of resource-saving technologies to the cultivation of winter wheat is defined on the basis of the data obtained from the farming enterprise "Anvar Jabborov" in Kamashi district, Kashkadarya province (Fig. 2) [8].

\subsection{Steps of Conducting Economic Evaluation}

Economic evaluation determines the overall and comparative effectiveness of technologies and techniques. The overall effectiveness defines the practicability of the applied innovation technologies and the comparative one helps to find out which are the most effective innovative technologies. The primary farm records and accounts were used for efficiency calculations. The activities were conducted in on-farm conditions using CA technology, when the sowing was done on November 11, 2014.

Moreover, economic evaluation of innovation technologies is determined according to their impact on improvement of the final figures of agricultural production, specifically, increment in profits achieved by means of increase in crop productivity, improvement of product quality, reduction of labor cost and reduction of production cost.

The steps of economic evaluation of $\mathrm{CA}$ and conventional agriculture are given below. These steps

\footnotetext{
${ }^{1} \mathrm{cwt}$ : hundredweight (a unit of weight equal to $100 \mathrm{~kg}$ ).
}

and formulas for economic evaluation were formulated according to Rustamova [9]:

(1) Economic evaluation indicators are identified for both practices (CA and conventional);

(2) The purpose of economic evaluation is determined, and based on that, tasks are formulated;

(3) Case study (as an example private farming "Anvar Jabborov" in Kamashi district, Kashkadarya region, Uzbekistan) is selected;

(4) Additionally, indicators of private farming are identified;

(5) Statistic data about agricultural lands, irrigated or rain fed lands, yields, costs (tangible) and prices for selling and buying are identified;

(6) Economic indicators for resource saving technologies (CA) and conventional agriculture are calculated and compared;

(7) Technologic calculation maps are provided for agricultural production;

(8) Net costs of agricultural products are calculated;

(9) Main and additional economic indicators are given based on basis, and new versions and alternative versions are identified.

\section{Results}

Traditional grain cultivation technology was taken as a basis for comparison. Under CA technology, grain seeds were sown in untilled soil or slightly loosened soil (to the depth of sowing) by the special seeding machines. It reduced the mechanical impact on the soil and soil panning due to alignment of technological operations using the combined units, and the operating costs were cut off 95,000 soums $^{2}$. It reduced the energy, material and labor costs associated with grain farming as well. The technological operations on winter wheat cultivation using the traditional and no-till technology are presented in Table 1.

Under the circumstances, the calculations were done considering application of the mechanical and

\footnotetext{
${ }^{2} \$ 1=2,405$ Uzbek soums as of December 1, 2014.
} 


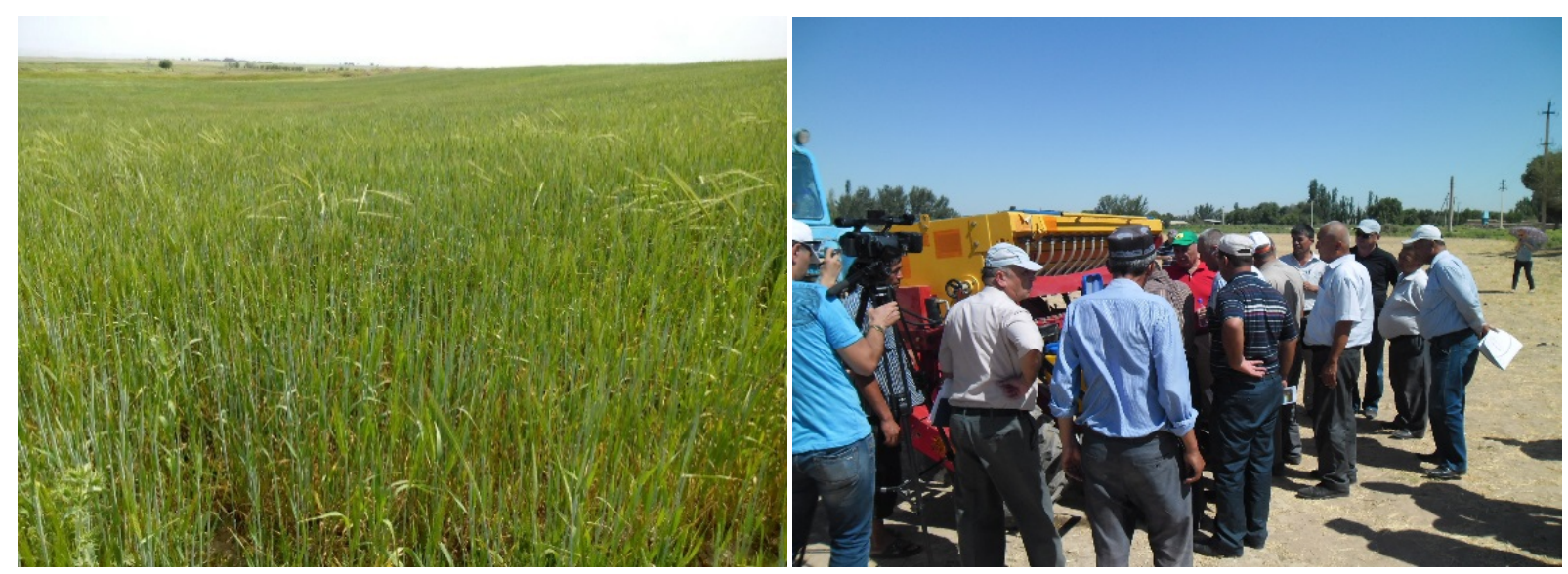

Fig. 2 Farming enterprise “Anvar Jabborov” in Kamashi district, Kashkadarya region.

Table 1 Technological operations and aggregates for winter wheat cultivation on a farm enterprise.

\begin{tabular}{|c|c|c|c|}
\hline \multicolumn{2}{|c|}{ Technological operations } & Traditional & CA \\
\hline \multicolumn{4}{|c|}{ Primary soil treatment } \\
\hline 1 & Mineral fertilizer handling & + & - \\
\hline 2 & Fertilizer transportation and application & + & - \\
\hline 3 & Fall-plowing & + & - \\
\hline 4 & Disking & + & - \\
\hline 5 & Harrowing & + & - \\
\hline \multicolumn{4}{|c|}{ Seed preparation for sowing } \\
\hline 6 & Seed transportation & + & + \\
\hline 7 & Sowing with fertilizer application & + & - \\
\hline 8 & Direct sowing & - & + \\
\hline \multicolumn{4}{|c|}{ Crop tending } \\
\hline 9 & Early spring harrowing & + & - \\
\hline 10 & Herbicide application & + & + \\
\hline \multicolumn{4}{|c|}{ Gathering and improvement } \\
\hline 11 & Swath selection and threshing & + & + \\
\hline 12 & Grain transportation & + & + \\
\hline 13 & Grain dressing and assortment & + & + \\
\hline 14 & Dragging & + & + \\
\hline 15 & Straw stacking & + & + \\
\hline
\end{tabular}

+ means use of the operations and - means not use of the operations.

technical complexes of the equipment, such as tractor fleet of the study area that provides power-operated services for the agro-engineering measures: plowing - 50,000 soums, disking-15,000 soums, harrowing - 15,000 soums, pre-planting and planting season-20,000 soums, transportation-10,000 soums, crop tending including early spring harrowing-15,000 soums and herbicides application-15,000 soums, harvesting and grain improvement $-80,000$ soums [10]. Totally, the power-operated service cost of the primary soil treatment per ha using the traditional technology made up 220,000 soums, whereas application of no-till technology was far more cost-saving and made up 125,000 soums.

The variants of winter wheat cultivation technology include the various techniques of the primary and 
pre-sowing soil treatment, crop tending and chemicalization. Gathering and improvement of grain and tailings are the same for all technologies. The technological operations and the winter wheat cultivation aggregates are set out with taking into consideration the peculiarities of zonal conditions, grain cultivation and gathering techniques unitized at performing the same type of work, rise in productivity, reduction of the mechanical impact on soil, increase of the performance standards based on the machine and technology system for the complex mechanization of farm production in a period of 2011-2016 [11, 12]. The economic evaluation settlements of the technologies are carried out according to the method of benchmarking analysis. Calculations of the primary profit and expenditure indicators are made with account of the data obtained from the Ministry of Agriculture and Water Economics of Uzbekistan [13]. The operating costs are calculated with account of the technical processes performed by the main machines and presented in Table 2.

The operating expenditures were calculated on the basis of the agreed prices for the power-operated services of the regional machine and tractor fleets. According to the data from Table 2, the highest operating expenditures for winter wheat cultivation and its gathering were spent when the traditional technology was used. It made up 397,190.4 soums. The lowest operating cost was obtained using CA and it made up 202,978.9 soums/ha of acreage. It is achieved due to reduction in soil treatment operations, which made up $36.4 \%$ from the total operating expenditures. The material expenditures on seeds, fertilizers and crop-protection agents for winter wheat cultivation using the technology under study are presented in Table 3.

The expenditures are left unchanged for both technologies. For protection from weeds at no-tillage

Table 2 Operating expenditures for wheat cultivation (on one ha basis)*.

\begin{tabular}{|c|c|c|c|c|c|}
\hline \multirow{3}{*}{ No. } & \multirow{3}{*}{ Name of work item } & \multicolumn{4}{|c|}{ Technology } \\
\hline & & \multicolumn{2}{|c|}{ Traditional } & \multicolumn{2}{|c|}{$\mathrm{CA}$} \\
\hline & & soums & $\%$ & soums & $\%$ \\
\hline 1 & Primary soil treatment & 80,000 & 36.4 & - & - \\
\hline 2 & Pre-sowing and sowing & 30,000 & 13.6 & 30,000 & 24.0 \\
\hline 3 & Crop tending & 30,000 & 13.6 & 15,000 & 12.0 \\
\hline \multirow[t]{2}{*}{4} & Yield gathering and grain improvement & 80,000 & 36.4 & 80,000 & 64.0 \\
\hline & Operating expenditures in total & 220,000 & 100.0 & 125,000 & 100.0 \\
\hline \multirow[t]{2}{*}{5} & Combustible and lubrication materials & $177,190.4$ & & $77,978.9$ & \\
\hline & Total expenditures for running machines & $397,190.4$ & & $202,978.9$ & \\
\hline
\end{tabular}

* Figures in December 2014.

Table 3 Costs associated with seeds, fertilizers and crop-protection agents for winter wheat cultivation per ha.

\begin{tabular}{lllllc}
\hline Material resources & \multirow{2}{*}{ Price per unit (soums) } & \multicolumn{2}{c}{ Resource level by technology } & & \multicolumn{2}{c}{ Costs by technology } \\
& & Traditional & CA & & Traditional \\
\hline Seed & $1,101.1$ & 100 & 100 & 110,110 & 110,110 \\
\hline Seeds (kg) & & & & & \\
\hline Mineral fertilizers & $1,599.9$ & 60 & 60 & 95,994 & 95,994 \\
\hline N fertilizers (physical mass, $\mathrm{kg})$ & & & & & \\
\hline Crop-protection agents & $81,536.0$ & 0.01 & 0.02 & 8,153 & 16,307 \\
\hline Weed killing by herbicide (kg/ha) & & & & & \\
\hline
\end{tabular}

Source: author's own compilation based on the data of the "Anvar Jabborov" farming enterprise. 
technology, herbicides are used twice as much as that at the traditional technology. Additionally to the expenditures, $2 \%$ from the direct costs was took, which made up 4,400 soums at the traditional technology and 2,500 soums at no-tillage technology, respectively. $50-60 \mathrm{~kg}$ of $\mathrm{N}$ fertilizers and $40-50 \mathrm{~kg}$ of $P$ fertilizers are applied when cultivating winter wheat in dry lands. $60 \mathrm{~kg}$ of $\mathrm{N}$ fertilizers were applied on this farm enterprise. A $75 \%$ herbicide "Granstar" is one of the most efficient fertilizers for weed killing in irrigated and rain-fed lands, from 10-20 $\mathrm{g}$ of the herbicide are applied per ha of sowing.

The secondary endpoints together with the core indicators enable to evaluate cost, labor, economical, energy and efficiency benefits and drawbacks of the technologies and techniques.

The indicators of economic effectiveness of the winter wheat cultivation in dry lands using no-tillage technology in comparison to the traditional one show the profitability of resource-saving technologies. The total cost, profit, cost effectiveness and secondary endpoints of winter wheat cultivation are calculated in

Table 4 Economic evaluation indicators of winter wheat cultivation at the farm enterprise.

\begin{tabular}{|c|c|c|c|c|}
\hline \multirow{2}{*}{\multicolumn{2}{|c|}{ Indicators }} & \multirow{3}{*}{$\begin{array}{l}\text { Measure unit } \\
\mathrm{cwt} / \mathrm{ha}\end{array}$} & \multicolumn{2}{|c|}{ Technologies } \\
\hline & & & \multirow{2}{*}{$\begin{array}{l}\text { Conventional } \\
10.0\end{array}$} & \multirow{2}{*}{$\begin{array}{l}\text { CA } \\
15.0\end{array}$} \\
\hline 1 & Harvesting capacity & & & \\
\hline 2 & Production volume & ton & 1.0 & 1.5 \\
\hline \multicolumn{5}{|c|}{ Production expenditures } \\
\hline 3 & Labor cost & soums & $140,000.0$ & $140,000.0$ \\
\hline 4 & Seeds & soums & $110,110.0$ & $110,110.0$ \\
\hline 5 & Mineral fertilizers & soums & $95,994.0$ & $95,994.0$ \\
\hline 6 & Crop-protection agents & soums & $8,153.6$ & $16,307.2$ \\
\hline 7 & Operation costs & soums & $220,000.0$ & $125,000.0$ \\
\hline 8 & Expenditures for combustion-lubricating materials & soums & $177,190.4$ & $77,978.9$ \\
\hline 9 & Miscellaneous costs & soums & $4,400.0$ & $2,500.0$ \\
\hline 10 & Cost summary & soums & $755,848.0$ & $567,890.1$ \\
\hline 11 & Unit costs & soums & $755,848.0$ & $378,593.4$ \\
\hline \multicolumn{5}{|c|}{ Production income } \\
\hline 12 & Wheat sell price & soum/ton & $447,260.0$ & $447,260.0$ \\
\hline 13 & Wheat income & soum/ha & $447,260.0$ & $670,890.0$ \\
\hline 14 & Straw income & soums & $150,000.0$ & $150,000.0$ \\
\hline 15 & Grain and straw income & soums & $597,260.0$ & $820,890.0$ \\
\hline 16 & Profit & soums & $-158,588.0$ & $252,999.9$ \\
\hline 17 & Economic effectiveness & soums & & $411,587.8$ \\
\hline 18 & Cost effectiveness & $\%$ & -21.0 & 44.6 \\
\hline \multicolumn{5}{|c|}{ Secondary endpoints } \\
\hline 19 & Labor costs per ha & man/day & 1.68 & 1.26 \\
\hline 20 & Labor costs per ha & man/hours & 0.24 & 0.18 \\
\hline 21 & Labor efficiency & $\mathrm{cwt} / \mathrm{man} /$ hours & 41.60 & 83.30 \\
\hline 22 & Labor intensity & $\mathrm{man} / \mathrm{cwt} /$ hours & 0.024 & 0.012 \\
\hline 23 & Diesel gas oil consumption & $\mathrm{L} / \mathrm{ha}$ & 84.12 & 37.02 \\
\hline 24 & Pay-back period & years & & 2.70 \\
\hline 25 & Normative land value & soums & 150,000 & 150,000 \\
\hline 26 & Land productivity & & 3.98 & 5.40 \\
\hline 27 & Land capacity & & 0.25 & 0.18 \\
\hline 28 & Materials-output ratio & & 1.27 & 0.69 \\
\hline
\end{tabular}


order to carry out the economic evaluation of the technologies (Table 4). The prime cost variations are determined by cost alterations for soil treatment and crop-protection agents, but costs for seeds and fertilizers remain equal.

The income from straw per ha made up 150,000 soums at the farm enterprise. From this perspective, the income from wheat and straw for both technologies was calculated and presented in Table 4. When evaluating farm labor input, the established standard is 0.03-0.04 employees per ha. On the farm with an acreage of 100 ha, three employees are employed. As the services on a farm are paid according to the completed work for a full season of wheat cultivation, the payment made 140,000 soums per ha.

At CA technology, the basic economic indicator "increment in profit" was calculated as Eq. (1):

$$
\begin{aligned}
\mathrm{Ca} & =P n-P t=252,999.9-(-158,588.0) \\
& =411,587.9 \text { soums }
\end{aligned}
$$

where, $\mathrm{Ca}-$ cost advantages at no-tillage technology;

$P t$ - profit at the conventional technologies;

$P n$ - profit at the no-tillage technologies.

Primarily, utilization efficiency of labor resources is characterized by labor efficiency and the retrograde measure of labor intensity.

Thus, at the traditional technology, labor efficiency and labor intensity were calculated as Eq. (2):

$$
\begin{gathered}
L e=\frac{V g}{T w}=\frac{10}{0.24}=41.6 \\
L i=\frac{T w}{V g}=\frac{0.24}{10}=0.024
\end{gathered}
$$

where, $L e$ is the labor efficiency, $L i$ is the labor intensity, $\mathrm{Vg}$ is the volume of gross output (cwt), and $T w$ is the work time expenditures (man/h);

At no-tillage technology, labor efficiency and labor intensity were calculated as Eq. (3):

$$
L e=\frac{V g}{T w}=\frac{15}{0.18}=83.33
$$

$$
L i=\frac{T w}{V g}=\frac{0.18}{15}=0.012
$$

Farm production output depends on productive resources utilization; foremost, it depends on land resources utilization. Land use efficiency is characterized by land productivity and land capacity and defined by the comparison of output production to acreage or standard land value.

Thus, at no-tillage technology, land productivity $(L p)$ and land capacity $(L c)$ were calculated as Eq. (4):

$$
\begin{aligned}
& L p=\frac{I g}{L v}=\frac{597,260}{150,000}=3.98 \\
& L C=\frac{L v}{I g}=\frac{150,000}{597,260}=0.25
\end{aligned}
$$

where, $L v$ is the standard land resources value, $I g$ is the volume of gross output (soums).

At no-tillage technology, land productivity $(L p)$ and land capacity $(L c)$ were calculated as Eq. (5):

$$
\begin{gathered}
L p=\frac{820,890}{150,000}=5.47 \\
L C=\frac{150,000}{820.890}=0.18
\end{gathered}
$$

Materials and output ratio indicates the degree of the material resources and equal to ratio of the material expenditures to the volume of gross output, as calculated in Eqs. (6) and (7) for conventional and no-tillage technology, respectively:

$$
\begin{aligned}
& M r_{1}=\frac{M e x}{I g}=\frac{755,848}{597,260}=1.27 \\
& M r_{2}=\frac{567,890}{820,890}=0.69
\end{aligned}
$$

where, $M r_{1}$ is the materials output ratio of traditional technology, $\mathrm{Mr}_{2}$ is the materials output ratio of conservation technology, Ig is the volume of gross output (soums) and Mex is the material expenditures. 


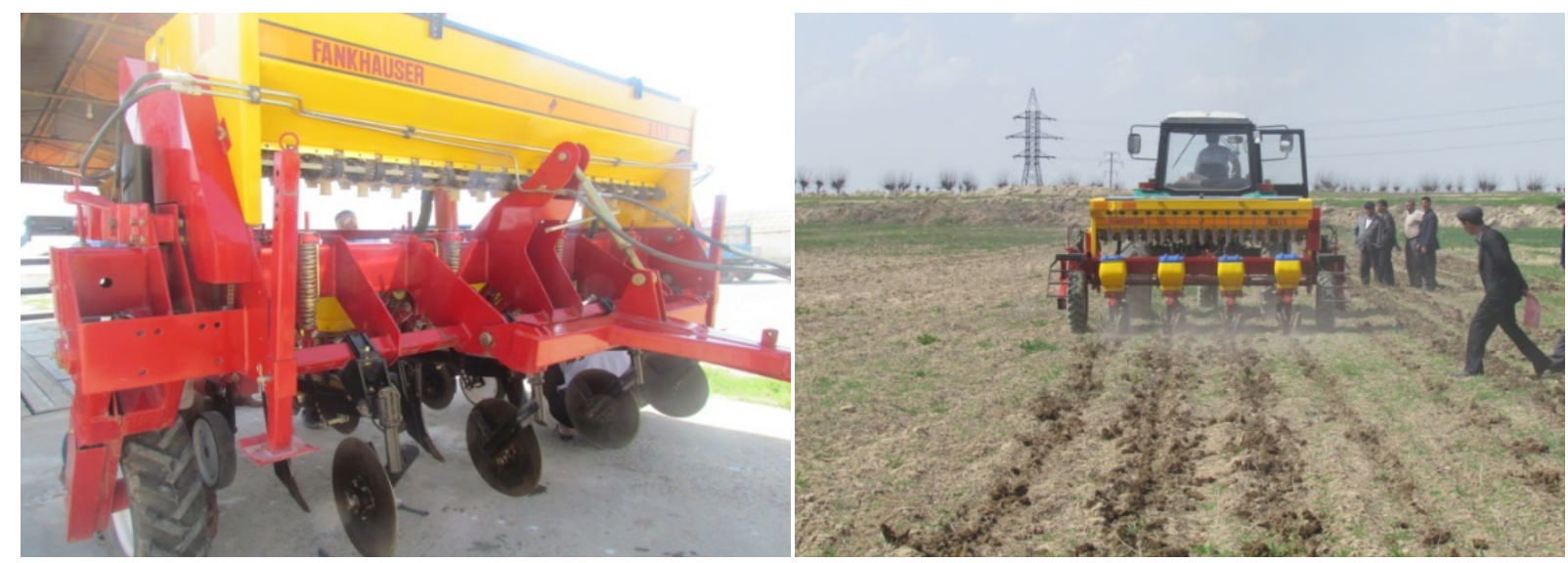

Fig. 3 Seeding machine FANKHAUSER.

Under CA technology, the materials and output ratio is two-folds lower than that at conventional one. Reduction in input of materials implies development of utilization of material resources and improvement of the economic effectiveness of the farm production. The profit level data show that application of winter wheat cultivation is economically advantageous. The harvesting capacity of no-tillage technology for winter wheat cultivation in comparison with conventional technology is 5\% much, and the production cost is respectively two-folds less.

At CA technology, the seeding machine of foreign manufacture FANKHAUSER-2115 (Brazil) at the cost of 28,000 USD was equal to $67,564,000$ soums factored in US dollar exchange rate at the period of December 2014. To the cost of the machine, there were additional costs in achieving the machine, for example transportation cost or administrative cost. If 1.1 as a coefficient, the book value was in the amount of $74,320,400$ soums. It meant that the machine's value was $74,320,400$ soums. The depreciation cost made up $8,249,564.4$ soums at the rate of $11.1 \%$. The purchased agricultural machinery is paid back for 2.7 years, if it is used on acreage of 200 ha. Subsequently, it will be used for seeding and planting other crops, as cotton, wheat, lentil and others.

The pay-back period of utilization of some certain machines, which economic evaluation is carried out according to "operation cost reduction" indicators is calculated on the basis of the book value of the machinery and reduction of operation cost associated with accomplishment of power-activated operations and depreciation costs compared to earlier utilized machinery. For the seeding machine FANKHAUSER (Fig. 3), the pay-back period was counted out as Eq. (8):

$$
\begin{gathered}
\text { Pay-back period }=\frac{V b}{C o p+C d} \\
=\frac{74,320,400}{19,000,000+8,249,564}=27
\end{gathered}
$$

where, $V_{b}$ is the book value (soums), Cop is the reduction of operation cost for power-activated operations (soums/year) and $C d$ is depreciation costs (soums/year).

Economic evaluation was done after implementation of the minimal and zero tillage practices for winter wheat production. The author gave these results from the case of private farming "Anvar Jabborov" in Kashkadarya province [8].

\section{Conclusions}

CA technology in terms of fuel consumption and labor costs was more effective than traditional way of agriculture.

CA technology of winter wheat cultivation is characterized by a high plane of labor intensity that is two-folds higher than conventional one, and has 
two-folds lower materials and output ratio. Utilization of the resource-saving technology with no-tillage treatment is considered more efficient under existing zonal conditions.

Generally, it can be mentioned that CA technology has benefits on the evaluation of economic indicators. Using no-tillage practices gives a chance to increase labour productivity, to use resource effectively and to improve soil quality and crop diversification. So, it is needed to raise awareness of $\mathrm{CA}$ among farmers to widely implement.

\section{References}

[1] Nurbekov, A. 2008. "Manual on Conservation Agriculture Practices in Uzbekistan." Agriculture Information System of Uzbekistan. Accessed August 2016. http://agriculture.uz/en.php?/ebooks/detail/895.

[2] Farooq, M., and Kadambot, H. M. S. 2015. "Conservation Agriculture: Concepts, Brief History, and Impacts on Agricultural Systems." In Conservation Agriculture. Switzerland: Springer International Publishing, 3-17.

[3] Abdullaev, I., Hassan, M. U., and Jumaboev, K. 2007. "Water Saving and Economic Impacts of Land Leveling: The Case Study of Cotton Production in Tajikistan." Irrigation and Drainage Systems 21 (3): 251-63.

[4] Mirtalipova, N. 2014. Potential of Conservation Agriculture Implementation on Carbon Sequestration in Tashkent Province.

[5] State Committee on Statistics of Uzbekistan. 2016.
“Statistic Data for 1991-2015.” Accessed October 7, 2016. http://www.stat.uz/en/.

[6] Agriculture of Uzbekistan. 2015. Statistical Collection. Tashkent: State Committee on Statistics of Uzbekistan.

[7] Rajabov, F. T. 2015. "Regional Features of Agriculture of the Republic of Uzbekistan (Illustrated Kashkadarya)." Socio-economical Geography Journal 7 (3): 108-15. (in Uzbek)

[8] Jabborov, A. 2014. "Farming in Kashkadarya Province." Accessed May 2015. http://www.cacilm.org/en/ecosystems/profile/30.

[9] Rustamova, I. B. 2016. Recommendations for Economic Evaluation of Technologies and Cultivation Methods in Agriculture. Tashkent: Tashkent State Agrarian University (TSAU), 80. (in Uzbek)

[10] Statistics of "Uzagromashservice" Association. 2014. Price Information on Material and Technical Resources and Delivered Services. (in Uzbek)

[11] Teshaev, S., Sultonov, B., Hushmatov, N., Toshboltaev, M., and Bayirov, M. T. 2011. Typical Flow Process Chart for Crop Cultivation and Manufacturing: Part I, 2011-2015. Tashkent: Hilol Media LLC, 80. (in Uzbek)

[12] Toshboltaev, M., and Bayirov, M. T. 2013. "System of Machinery and Technologies for the Complex Mechanization of Agricultural Production for the Period of 2011-2016. Tashkent: Scientific Research Institute of Mechanization and Electrification of Uzbekistan, 106-7. (in Uzbek)

[13] Materials of the Ministry of Agriculture and Water Resources of Uzbekistan. 2014. Price Information on Agricultural Products, Material and Technical Resources and Delivered Services. (in Uzbek) 